
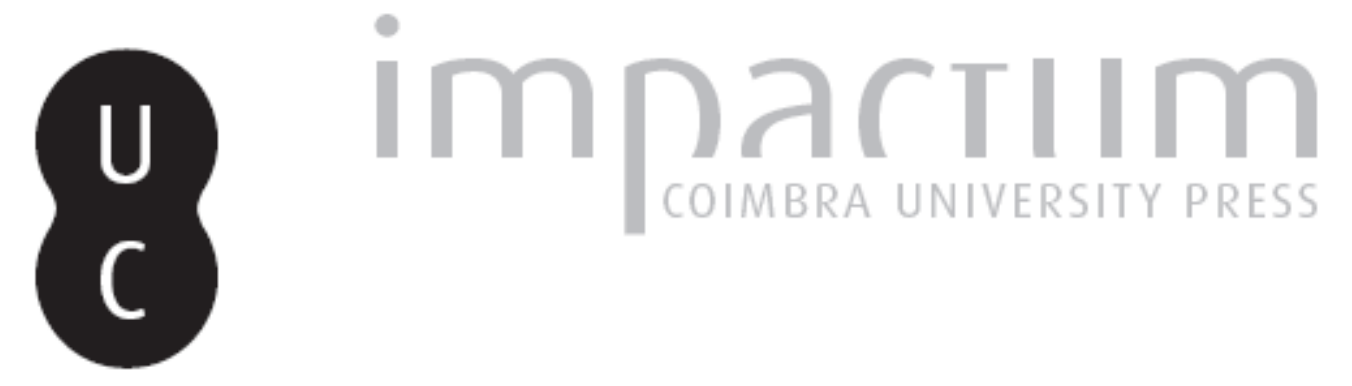

\title{
[Recensão a] Browne, K. 2001. Trabalhos divididos: uma perspectiva evolutiva das mulheres no trabalho
}

\author{
Autor(es): $\quad$ Alvarez, Manuela \\ Publicado por: CIAS - Centro de Investigação em Antropologia e Saúde \\ URL \\ persistente: \\ URI:http://hdl.handle.net/10316.2/41284 \\ DOI: \\ DOI:http://dx.doi.org/10.14195/2182-7982_18_12 \\ Accessed : $\quad$ 26-Apr-2023 13:21:22
}

A navegação consulta e descarregamento dos títulos inseridos nas Bibliotecas Digitais UC Digitalis, UC Pombalina e UC Impactum, pressupõem a aceitação plena e sem reservas dos Termos e Condições de Uso destas Bibliotecas Digitais, disponíveis em https://digitalis.uc.pt/pt-pt/termos.

Conforme exposto nos referidos Termos e Condições de Uso, o descarregamento de títulos de acesso restrito requer uma licença válida de autorização devendo o utilizador aceder ao(s) documento(s) a partir de um endereço de IP da instituição detentora da supramencionada licença.

Ao utilizador é apenas permitido o descarregamento para uso pessoal, pelo que o emprego do(s) título(s) descarregado(s) para outro fim, designadamente comercial, carece de autorização do respetivo autor ou editor da obra.

Na medida em que todas as obras da UC Digitalis se encontram protegidas pelo Código do Direito de Autor e Direitos Conexos e demais legislação aplicável, toda a cópia, parcial ou total, deste documento, nos casos em que é legalmente admitida, deverá conter ou fazer-se acompanhar por este aviso.

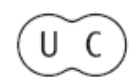


Antropologia Portuguesa

Volume $18 \cdot 2001$

Departamento de Antropologia | Universidade de Coimbra 
do, para isso, diversas características para interpretar fósseis de hominídeos, chamando, assim, a atenção sobre o crescimento humano préhistórico. Esta abordagem culmina no capitulo Evolution of human life cycle que é a grande tese do autor, começando com um argumento conciso para o entendimento biocultural do crescimento humano. Após uma breve discussão sobre neotenia ele desenvolve o conceito de dois estádios: "childhood" e adolescência; para isso Bogin apresenta um extenso argumento justificativo no que diz respeito à evidencia destas adições e qual a interpretação da sua origem e do seu significado evolutivo. Este capitulo representa, na minha opinião, a importante contribuição de Bogin para o estudo do crescimento e do desenvolvimento humano. Nem todos os autores concordam com estas conclusões mas, ainda, ninguém as soube contrapor.

Patterns of human growth pode assim ser considerado um manual imprescindível, quer para estudantes de antropologia, quer para investigadores mais avançados nesta área do conhecimento. Consegue ser extremamente elucidativo e claro e, simultaneamente, informativo e actualizado.

\section{Cristina Padez}

Departamento de Antropalogia

Universidade de Coimbra

3000-056 Coimbra, Portugal

cpadez@ci.uc.pt

Browne, K. 2001. Trabalhos divididos: uma perspectiva evolutiva das mutheres no trabalho. Coimbra, Quarteto (Tit. original: Divided labours: an evolutionary view of women at work, 1999). 89 p. ISBN 972-871-714-8. $€ 7,50$.

O tema central deste livro são as assimetrias sexuais que se observan no mundo do trabalho, e a sua razão de existir. Perante uma realidade em que as mulheres estão subrepresentadas nos níveis mais altos das hierarquias e em que a média dos seus vencimentos é inferior à dos homens, o autor sugere que diferenças biológicas básicas inerentes à diferenciação dos sexos e codificadas geneticamente, sejam responsáveis pelas diferenças comportamentais observadas entre homens e mulheres. Agindo no contexto do moderno mercado de trabalho, tais diferenças deram origem ao chamado "fosso" entre os géneros. 
Baseado em alguns estudos do campo da psicologia cognitiva e da genética comportamental, o autor apresenta o que considera ser uma prova indubitável do carácter natural do comportamento humano, a predisposição inata para incorporar um papel sexual definido. Durante a epigénese, as hormonas sexuais promovem o desenvolvimento dos órgãos sexuais e programam o cérebro para incorporar um papel sexual definido, masculino ou feminino. A acção organizadora e activadora das hormonas sexuais prolonga-se até ao estado adulto conduzindo ao desenvolvimento de estilos comportamentais distintos para cada um dos sexos que, mais tarde, se vão repercutir no local de trabalho. Os homens são mais competitivos, querem ganhar mais dinheiro, optam por horários mais longos e condições de trabalho mais desagradáveis - o sucesso extradoméstico é a sua principal fonte de autoestima. $\mathrm{O}$ desempenho profissional das mulheres é diferente. As mulheres estão menos dispostas a correr riscos, quer sejam físicos ou de "carreira", não atribuem tanta importância aos aspectos financeiros do trabalho e valorizam outras características tais como: condições de trabalho mais seguras, flexibilidade de horários e a oportunidade de ajudar os outros, preferências que, segundo o autor, podem ser levadas em conta para a concentração de mulheres em empregos na função pública. Por outro lado, as mulheres atribuem grande importância ao envolvimento com os filhos e, ao contrário dos homens, tendem a encaixar o trabalho com as familias, onde vão buscar um elevado nível de satisfação pessoal. A conclusão de que os diferentes compromissos dos sexos revelam simplesmente que eles tem prioridades diferentes, motivadas pela sua biologia, conduz o leitor aos porques que põem fim a todos os porquês, isto é, aos fins que justificam os meios: as diferentes prioridades dos sexos são o reflexo de estratégias reprodutivas distintas, desenvolvidas com o objectivo comum de maximizar o seu sucesso reprodutivo.

Para Kingsley Browne, no que toca à reprodução, o homem não difere muito dos restantes mamíferos, em que os indivíduos do sexo que investe menos, os machos, competem entre si por oportunidades de acasalamento, via decisão das fêmeas ou competição entre machos. Ao terem numerosas parceiras podem aumentar o seu sucesso reprodutivo, de uma forma que as fêmeas não podem porque têm de transportar as crias durante o periodo de gestação, e de cuidar delas até se tomarem auto-suficientes. Os padrões agora observados na moderna sociedade Americana, considerada modelar, não são, por isso, um artefacto cultural resultante de políticas sociais desasjustadas ou discriminatórias, mas um fenómeno natural, produto de 
uma escolha feminina desde há muito inscrita no património genético da humanidade. Traços de personalidade, tais como a dominância e a capacidade de correr riscos, seriam valiosos para os homens no seu ambiente ancestral, e eram os escolhidos preferencialmente pelas mulheres, permitindo-Ihes serem pais de muitas crianças, o que explica a sua prevalência na sociedade actual.

A competitividade dos homens fica assim equiparada à vistosa cauda do pavão, ou às dispendiosas hastes do veado usadas nas lutas entre machos pelo acesso às fêmeas. Evoluiu por selecção natural por aumentar o sucesso reprodutivo dos seus portadores. A ideia não é original, e parece dar continuidade a mote alheio: "... pensar que a cauda do pavão se formou assim; mas, acreditando nisso, acredito no mesmo princípio, ligeiramente modificado, aplicado ao homem." (Charles Darwin, carta citada em Desmond e Moore, 1991:553').

$\dot{E}$ um facto que as sociedades se compõem de seres humanos que, enquanto mamiferos, têm de obedecer aos princípios da biologia que engloba todos os mamíferos. Os mamíferos, por seu turno, compõem-se de moléculas que têm que obedecer às leis da química, que por sua vez, tem de dar resposta à regularidade da fisica subjacente. O cérebro humano é uma entidade física sujeita a todas as leis da física e da química, e a percepção do seu funcionamento não está para além do alcance da ciência. Contudo, a invasão do cérebro humano pela cultura, criou a perspectiva de uma relação complexa entre herança genética e herança cultural, modelando a mente e conferindo-lhe autonomia para transcender os genes "egoístas". A contribuição da cultura para a compreensão do comportamento humano dificulta a nossa percepção da selecção natural genética: os genes estão associados a cromossomas lineares e devem ocupar loci que contenham vários alelos identificáveis, com replicação diferencial. Esta dificuldade não é, porém, partilhada por Browne (2002: 24) para quem "a competição pelos parceiros cria vencedores e vencidos na lotaria genética da vida, e a maior variação reprodutiva dos machos coloca mais altas as fasquias em jogo para eles próprios do que para as fêmeas. (...) Os genes influenciam o nosso comportamento não por nos conduzirem pela vida como marionetas suspensas por fios de $\mathrm{ADN}$, mas pela equipagem dos nossos cérebros com os instru-

' Desmond, A.; Moore, J. 1991. Danwin. Londres, Michael Joseph. 
mentos necessários à apreensão e ao processamento da infonnação relevante para a resolução dos problemas do nosso passado evolutivo. Estes mecanismos (...) são discretos instrumentos mentais na dependência dos estímulos exteriores mais importantes para a produção de comportamentos adaptativos." Estas são apenas algumas das muitas frases cujo conteúdo mereceria ser analisado e discutido, o que decerto não caberia numa pequena recensão como esta. Servem apenas para alertar o leitor que este discurso, apesar de convincente, apresenta armadilhas, as chamadas "sobressimplificações" da sociobiologia popular. Fazendo parte de uma colecção intitulada "Darwinismo Hoje", com o objectivo de divulgar a um público mais vasto "o novo Darwinismo" e a sua aplicação aos problemas comuns, esta obra acaba por denunciar, voluntariamente ou não, um dos pecados mais comuns de que a teoria de Darwin tem sido alvo, o reducionismo. Isto é, quando se substimam as suas complexidades, passando por aspectos incontornáveis da teoria e de fenómenos reais, na ânsia de reduzir, unir e explicar tudo numa grande teoria global.

\section{Manuela Alvarez}

Departamento de Antropologia

Universidade de Caimbra

3000-056 Coimbra, Portugal

alvarez@i.uc.pt

Daly, M.; Wilson, M. 2001. A verdade sobre Cinderela: uma visăo darwiniana do cuidado parental. Coimbra, Quarteto Editora. (Tít. original: The Truth About Cinderella: A Darwinian View of Parental Love, 1999). 80 p. (Darwinismo Hoje).ISBN 972-871-713-X.€ 7,50.

Smith, J. M. 2001. Modelando a vida: genes, embriōes e evolução. Coimbra, Quarteto Editora. (Tít. original: Shaping Life: Genes, Embryos, and Evolution, 1999). 57 p. (Darwinismo Hoje). ISBN 972-871-715-6.€ 7,50.

A importância da teoria da evolução de Darwin está claramente estabelecida na Biologia e áreas afins, como a Antropologia Biológica. Como escreveu 'Theodosius Dobzhansky (1973)', nada em Biologia faz sentido

' Dobzlansky, T. 1973. Nothing in Biologr' makes sense except in the light of evohttion. http://www.pbs.org/wgbh/evolution/library/10/2/l_102_01.html [Acedido em Novembro de 2002]. 